\title{
Pan-African Judgments on the Gulf Investments in Oppressive Governments
}

\author{
Mahgoub El-Tigani Mahmoud \\ Tennessee State University
}

doi: 10.19044/esj.2017.v13n13p1 URL:http://dx.doi.org/10.19044/esj.2017.v13n13p1

\begin{abstract}
The African ancient civilizations played influential roles in global trade and power relations; in recent histories and contemporary times, persistent failures of dependent economies and political leaderships underdeveloped the continent by oppression and manipulative investments. Focusing on the African Charter on Human and Peoples' Rights, our paper applied a Pan-Africanist framework to assess the impact of Gulf States' investments on the African setting. The paper stressed the predetermined cycle of investments that exchanged massive flows of the collected and/or accumulated surpluses into the Gulf, Chinese, and other foreign investors, whereas the poorest African most targeted recipients were the least benefitted. Despite the ambiguity and scarcity of accessible information on the Gulf/African businesses, we have heavily drawn available facts from United Nations and international sources, as well as critical views by PanAfrican scholars, human rights' activists, and political opponents. To ensure sustainable development free of exploitation and abuse of authority for the African peoples, foreign investors should avoid the past colonial and/or neocolonial ventures that dispossessed the land and manpower of the Continent, reinstated wealth-and-power thirst rulers in authoritative systems of rule, and impoverished indigenous farmers and the low-income workers and professionals with lasting poverty.
\end{abstract}

Keywords: Pan-Africanism, African Charter, foreign domination, Gulf business, investment, underdevelopment, human rights

\section{Introduction}

Africa was a haven of ancient prosperity and human flourishment. In the fourteenth century, the African thinker 'Abd al-Rahman ibn Khaldun (1332) theorized in his Muqadimah [introduction] the impact of different climates and natural environments on people's attitudes and social interactions (Baali, 1988; Ibn Khaldun, 1997). In the twentieth century, the 
African scholar Cheikh Anta Diop (1923-1986) developed an Africancentered theory with weighty reliance on European writings on Africa and Europe. The Civilization's Two Cradle Theory (1963) was well-celebrated in the studies of cultural anthropology, history, and sociology on the origins of human thought, societal behavior, and domains of the individual and social life. Diop believed the human geography climate, resources, and other factors shaped the social life's attitudes of the two continents in a very different way: the European North Cradle of civilization resembled a life of hard struggles to ensure survival in the face of a hostile nature, thus bringing about an array of social structures and attitudes favorable to the prevailing conditions and hardships of life. Contrariwise, the African South Cradle of Civilization flourished as a nature-loving society with abundant resources, optimistic perspectives, and collective forms of thought (Diop, 1986:47102).

The Bedouin cultures of the Arab Peninsula exhibited same characteristics of the Southern Cradle's extended families and Saharan solidarity. But the small emirates of the Peninsula were not comparable to the colossal civilizations of Africa. The Peninsula, however, was the promised land of Islam's universal civilization which embraced great space of the world. Since old ages, Arabia exercised active exchanges of migration and trade in neighborly relations with Africa. In the Year of the Elephant (570 CE) though, Ethiopia led an abortive expedition to conquer Mecca. But in 614 A.D., the Ethiopian "King Armah (Negash) granted refuge to the family of the Prophet Mohammad [pbuh] that arrived at Aksum while fleeing from their pagan persecutors” (Tadias Staff: 2008). In 638 CE, a Muslim caliphate governed Egypt as the Monophysite Christians "saw the Arabs as liberators. So too did Egypt's peasants, who had felt oppressed by tyrannical, mostly Greek, landlords” (Macro History, 2007). Besides the experiences of ruling elites and foreign domination in the old ages, and the trade and cultural linkages with the Islamic Mali, Songhai, Fulani, and Funj empires and the kingdoms of Morocco, Chad, and Darfur, the modern histories of the Gulf and Oman Emirates, the Kingdom of Saudi Arabia, and the Republic of Yemen shared large populations of the African manpower of which millions of Muslims exercised pilgrimage to the Holy City of Mecca.

The Mother Continent was well-known for the deep spirituality of her peoples who maintained many indigenous belief systems, in addition to the majority Africans who believed in Christianity and Islam monotheistic religions. Unlike their Muslim neighbors whose understanding of religion emphasized the Shari'a legal rulings, the African Muslims adopted largely the Sufi Islam that recognized their love of Nature as corresponding to the fitra normality, the essence of Shari'a realization of personal freedoms and the values of equity, justice, and human solidarity. These same values 
influenced the trade and commercial transactions of the African domestic markets which continued to rely heavily on the verbal words of spiritual trust based on the family and community collaterals and ethno-religious junctions. Needless to say, these indigenous values were simply ignored by the Arab and Chinese businesses that signed bilateral contracts with government agencies in recent times to construct hydroelectric dams among lucrative ventures misappropriating vast agricultural lands and displacing pharmaceutical production.

This particular pattern of underdevelopment seemed to be rooted in the political heritage of the Gulf. Documenting a long history of conflicts between the ruling Sheikhs and contending merchants under British administration, Oil and politics in the Gulf Rulers and merchants in Kuwait and Qatar concluded, "Oil brought new forces which restructure political life. Within a few years of the postwar resumption of operations, oil revenues dominated both economies... Most critically for politics, these revenues, rents, are paid directly to the state or, in the Gulf, the rulers. One consequence of these revenues is to affect the independent power of social groups and to weaken the links between state and society. A second is to increase the power of the state" (Jill Crystal, 1990:6). Regardless of the absence of formal information on the multi-million deals of Qatar with the ruling regime in Sudan, for example, it wasn't difficult to assume that the Qatari investments in Africa applied similar strategies to "pay directly to rulers” and the rest. These and other related issues would be analyzed in the section on the Gulf Investments in Africa.

All in all, the negative attitudes of foreign investors perpetuated nondemocratic rule and dehumanized society: "The most serious threat to democracy, civil society, and reform remains, in the impoverished economies of African states. Democracy will not take root in Africa if the majority of its population continues to live in abject poverty. Africans support democracy because they expect it to reverse decades of corruption, mismanagement, and economic hardship. Only innovative domestic economic policies coupled with a reform of the international economic arrangements to take into account the difficult conditions of African states can create the conditions necessary for human development” (Mutua, 2000:38).

For hundreds of years, the African peoples who used to maintain good neighborly links with European and Arab counterparts became a subject of slave trade up to the nineteenth century when the shameless activity was finally outlawed by international law. Postcolonial Transitions in Europe, Contexts, Practices and Politics indicated: "demographic colonialism... In the various Eurafrican partnerships that have been promoted since the 1920s, power and agency have always been on the 
European side, while Africa has figured as a safety valve ensuring Europe's bio-political stability. Each time demography has governed European migration policy vis-à-vis Africa, what has first been introduced as a mutual interest, or as a "partnership of equals," has quickly been transformed into a geopolitical relationship, where one partner has sought to manage migration to its own benefit” (Ponzanesi \& Colpani, 2016:61-2). The African suicidal trips to Europe by ill-equipped boats across the Mediterranean flagged a most dehumanizing context of this demography.

"The International Covenant on Economic, Social and Cultural Rights recognizes the right to work 'which includes the right of everyone to the opportunity to gain his living by work which he freely chooses or accepts' (art. 6(1)). In articles 5, 7, and 8 the Covenant further sets certain conditions and rights that must be upheld and protected by the States parties such as fair wages and equal remuneration for work of equal value and the right to form and join trade unions” (David Weissbrodt and Anti-Slavery International; OHCHR, 2002:7-8). Unfortunately, the international protection of wage labor was reportedly violated in Middle-East markets versus Asian and African labor, albeit reservedly resounded in the Gulf media (Al Jazira, 2016). In Kuwait, "Labor ministers from Gulf and Asian countries should improve labor law protection, reform abusive immigration policies, and increase dialogue with trade unions and nongovernmental groups, 90 human rights organizations and unions said. Millions of contract workers from Asia and Africa, including an estimated 2.4 million domestic workers in the Gulf, are subject to a wide range of abuses, unpaid wages, confiscation of passports, physical abuse, and forced labor" (Human Rights Watch, 2014).

"Qatar Gulf State with its infamous kafala system can be a living hell for migrant laborers, excluded from labor law and under a forced labor system akin to a modern slavery. The situation in Saudi Arabia is similar for in Saudi Arabia, which employs a staggering 8.3 million migrant's make up 90 to 95 per cent of the private sector workforce but are excluded from labor law and endure forced labor akin to slavery. The slow legal system means many are stranded without work but without the ability to go home. In the United Arab Emirates, non-national workers make up more than 88 per cent of the population. Migrants are excluded from labor law and endure forced labor, with excessively long hours, seized passports and changed contracts a part of working life. Migrant workers in UAE also don't have the right to join a union or go on strike, so those that speak up risk prison and deportation” (The World Post, 2017). 


\section{The Pan-African Movement}

The African thought has been remarkably geared and engineered to address reality with a view to help enforce an optimum change Maulana Karenga eloquently conceptualized as "the activist-intellectual tradition... This tradition extends back to ancient Egypt with its model of the socially conscious and activist intellectual, the sesh, who understood themselves in both moral and social terms and constantly expressed a commitment to using their knowledge and skills in the service of the people... improving the human condition and enhancing the human prospect” (Karenga, 1993:7-8). Marcus Garvey, W.E.B. DuBois, and Frederick Douglass emphasized the need to strengthen the oneness of Africans by all possible economic, ideological, and political ties. "The whole history of the progress of human liberty shows that all concessions yet made to her august claims, have been born of earnest struggle. If there is no struggle there is no progress. Those who profess to favor freedom and yet depreciate agitation, are men who want crops without plowing up the ground, they want rain without thunder and lightning. They want the ocean without the awful roar of its many waters" (Douglass, 1857; cited in BlackPast, 2007).

Since contemporary conditions of the African peoples in Diaspora and the Continent continued to face enduring hitches of the passing centuries, it was appropriate to rethink this situation in light of the PanAfricanist thought. Throughout the twentieth century, W. E. B. Du Bois and Pan-African leaders provided intriguing intellectual and practical possibilities to develop a successful international movement that would necessarily build-up progressive bondages between African-descent populations all over the world. By the mid-sixties, Kwame Nkrumah led with William Du Bois the Pan-African Movement triumphantly to motivate the African heads of state to create the Organization of African Unity (OAU) in Addis Ababa, 1963. Along with the 1960s' momentum of independence and liberation movement, the following years saw the African Charter for Human and Peoples’ Rights (1981) which adopted a clear Africanist orientation.

The Pan-Africanist leaders were gravely concerned for the sabotage of African history in the Diaspora. In 1935, Du Bois addressed the issue movingly in Black Reconstruction in America. The success of Black Americans in constitutional governance right after the Reconstruction [186577, the period of readjustment following the American Civil War] granted them the right to vote. "We may recognize three things which negro rule gave to the South: 1. Democratic government. 2. Free public schools. 3. New social legislation” (Du Bois, 1935:795-6). Two decades later, Cheikh Anta Diop "found it more judicious to make the necessary effort to rediscover the general history of the Black world and that of the African world in particular. From such knowledge of our past, it will be possible to establish the African 
contribution to world progress by a simple comparative method, beginning with the fundamental traits of African culture and taking into account chronology... the notion of culture is tied to the emergence of a multinational state embracing almost the entire continent” (Diop, 1996:114).

The Post-Colonial Africa: The African [Banjul] Charter's Preamble stipulated that "freedom, equality, justice and dignity are essential objectives for the achievement of the legitimate aspirations of the African peoples " (ACHPR, 2017). The Charter aimed "to eradicate all forms of colonialism from Africa; coordinate and intensify cooperation and efforts to achieve a better life for the peoples of Africa; to pay a particular attention to the right to development and to the fact that civil and political rights cannot be dissociated from economic, social and cultural rights; and achieve the total liberation of Africa, the peoples of which are still struggling for their dignity and genuine independence” (ACHPR, 2017). These tenable provisions by the continent's post-independence forefathers of whose anti-colonialist struggles the Charter was radically wrought, were not consistently implemented by many succeeding leaders, rulers, or governments.

Article 17-2 of the Charter emphasized the significance of traditions in Africa: "Every individual may freely, take part in the cultural life of his community. 3. The promotion and protection of morals and traditional values recognized by the community shall be the duty of the State." Article 18-1 "The family shall be the natural unit and basis of society. It shall be protected by the State which shall take care of its physical health and moral. 2. The State shall have the duty to assist the family which is the custodian or morals and traditional values recognized by the community. 3. The State shall ensure the elimination of every discrimination against women and also ensure the protection of the rights of the woman and the child as stipulated in international declarations and conventions. 4. The aged and the disabled shall also have the right to special measures of protection in keeping with their physical or moral needs."

Article 21-1 "All peoples shall freely dispose of their wealth and natural resources. This right shall be exercised in the exclusive interest of the people. In no case shall a people be deprived of it. 2 In case of spoliation the dispossessed people shall have the right to the lawful recovery of its property as well as to an adequate compensation. 3. The free disposal of wealth and natural resources shall be exercised without prejudice to the obligation of promoting international economic cooperation based on mutual respect, equitable exchange and the principles of international law. 4. States parties to the present Charter shall individually and collectively exercise the right to free disposal of their wealth and natural resources with a view to strengthening African unity and solidarity.” 
The founding fathers of the Charter were crystal clear about the negativities of foreign investments, especially if they failed to cater equally for the needs and claims of native Africa. Article 20-3 of the Charter dictated, "All peoples shall have the right to the assistance of the States parties to the present Charter in their liberation struggle against foreign domination, be it political, economic or cultural.” Nonetheless, “all forms of colonialism" were not yet eradicated; the virtues of African cooperative and collective cultures were seriously interrupted by the expansion of foreign investments that spared no vantage of profit-making from within the virgin lands and laden resources of the continent, with scant or no concern for the direct results of these transformations in the life of the majority indigenous farmers, poor workers and state employees.

This paper did not discuss in detail the extent to which African peoples took advantage of foreign investments in the last twenty years or so. Persistent high infant mortality rates (IMR), low levels of literacy, outstanding service debt, and high ranks of uncontrolled state corruption testified to the failures of overwhelming foreign investments to benefit the majority of Africans, as well as default of the ruling leaderships to show deserved allegiance to the people they undeservedly ruled. The repressive relationships of African governments with African people constituted egregious violation of the African Charter's emphasis on public freedoms and human rights (Article 9-1 the right to receive information; Article 10 the right to free association; Article 11 the right to assemble freely with others; Article 12 the right to freedom of movement and residence; Article 13 the right to participate freely in the government; and Article 14 the right to property "which may only be encroached upon in the interest of public need or in the general interest of the community").

Article 30 of the Charter authorized an African Commission on Human and Peoples' Rights “to promote human and peoples' rights and ensure their protection in Africa” (OAU, 1982). Notwithstanding, the human rights' reports on the commitment of African states to the Charter's fundamental rights and genuine freedoms documented the poor application of obligations. The Commission's records implicated a dire need to find the principled leaders who could only be tested by consistent democratic programs in the political, cultural, and educational arenas (Mahmoud, 2005). None of these was reliably applied as military coups and corrupted governments perpetuated the authority-made leaderships. "African leaders admit that the major reason for Africa's social, political, and economic crisis is bad leadership... Kofi Anan, a former Secretary General of the United Nations from Ghana, was blunt in advising African chiefs to stop blaming colonial powers and colonialism for Africa's ineffective leaders, political and economic woes, and current level of underdevelopment” (Udogu, 2016:2). 
"Although the Banjul Charter makes a significant contribution to the human rights corpus, it creates an ineffectual enforcement system. Its most notable contributions are the codification of the three "generations" of rights, including the innovative concept of peoples' rights, and the imposition of duties on individuals... the weaknesses in the African system include the "clawback" clauses in the African Charter, the potential abuse of the language of duties, and the absence of an effective protection mandate for the African Commission... demands for more open political societies may augur well for the protection of civil and political rights. In this context, the African Human Rights Court is likely to operate states themselves” (Mutua, 2000:38). Following a short period of democratic governments in Nigeria, Sudan, Namibia, Malawi, Benin, South Africa, Tanzania, and Mali that were enthusiastically received by the masses as promising anti-colonial systems of rule, the lacking of confidence between people and government never stopped.

Colonialism undoubtedly laid the foundation of this situation through the injustices colonial authorities developed when they ruled the continent. The nationalist governments were blamed for the development failures, authority abuse, and a wide range of gross human rights violations against the Africans. Governments failed to make peace with the people by authoritative governance. Nobel Laurette Woll Soyinka (1975) criticized the severe repercussions of state intrusions in the peaceful competition for power: "the king has died, and his horseman is expected by law and custom to commit suicide and accompany his ruler to heaven." The human rights' situation was appalling throughout the post-independence period. In the 1980s, Africa resisted by both civilian and armed struggles the dictators who clothed military tyrannies with single-party single-candidate presidential systems in almost every part of the continent.

The records of most state leaderships in and after the Cold-War Era antagonized the meaningful principles that the independence forefathers inculcated meticulously in the histories of independence. "Democracy hinges on 1) a principled allowance by states for the popular participation of civil society in national decision making; and 2) a constant commitment by both state and civil society to demonstrate government systems and societal life.” But the momentum of democratic transition unfolded in a new pattern of authoritarianism rather than stable democracy: By the 1990s, "the reality of state interference in academic or private freedoms, excessive use of force, and unlawful violence characterized the performance of many African governments" (Mahmoud: 2005:19). The situation was further worsened by the tendency of central governments to marginalize the countryside with uneven development, underdevelopment, and a complete negligence of modern services and amenities. 
In Nigeria, Sudan, Gambia, and Niger, as well as Mauritania and Tunisia, security leaders replaced democratic rule by rituals of self-appointed institutions. The transition of Gambia to elected leadership was 'extremely flawed.' "Having promoted himself from lieutenant to colonel after the military coup of July 1994, Jammeh announced through the commission of gross human rights violations, intimidation, and persecution of political opponents the beginning of a new era of freedom, progress, democracy, and accountability” (John A. Wiseman, 1998:65-75). In the late 1990s, political analysts were wondering whether "President Yoweri Museveni of Uganda, Prime Minister Meles Zenawi of Ethiopia, President Asias Afewerki of Eritrea, and Vice President and Defense Minister - and de facto head of government - Paul Kagame of Rwanda represent African solutions to African domestic and regional problems, or are they a new African problem?... Their plea that the international community should understand the special problems their countries face and allow them to blaze their own path to democracy can be interpreted as a realistic assessment but also as a weak excuse for authoritarianism” (Ottaway, 1998:199; cited in Mahmoud, 2005:40).

Another side of failure pertained to a cult of leadership apart from the leader's competencies. Ali Mazrui's analysis of this phenomenon illuminated "the tendency towards monarchism and the personality cult among some African leaders has hindered the development of strong public institutions... in terms of four factors: the quest for aristocratic effect, the personalization of authority, the sacralization of authority, and the quest for a royal historical identity - The personality cult often leads to the destruction of the opposition and the subsequent weakening of democratic institutions... Ali Mazrui appreciates Nkrumah's vision for Africa and his ability to inspire Ghanaian nationalism. He views Nkrumah as an exemplary leader who had great goals and who could design appropriate strategies for realizing some of his goals... he also sees him as a leader who lost the vision for his country because he was wrapped up in the personality cult. For Mazrui, Julius Nyerere of Tanzania was "an exemplary figure who shied away from the personality cult. He admires Nyerere's originality of thought, intellectual stature, selfeffacing character and consistent support for the pan-Africanist dream. But he was critical of Nyerere's anti-intellectual policies and experiment with socialism” (Mazrui and Mutunga, 2003:4-6).

These criticisms did not deny the great efforts of the Continent's national liberation leaders who moved Africa into a path of development commensurate with the needs and aspirations of the rural populations and the deprived residents of the cities. It was Kwame Nkrumah, Ahmed Sékou Touré, Gamal Abd al-Nasser, Julius Nyerere, Jomo Kenyatta, Ahmed Ben Bella, Nelson Mandela and Patrice Lumumba, as well as political theorists of 
the caliber of Amilcar Cabral, 'Abd al-Khaliq Mahgoub, Ali Mazrui, and Gilbert Rodney together with leading Africans in the Diaspora led by Marcus Garvey, W. B. Du Bois, Martin Luther King, Jr., El-Hajj Malik El-Shabazz [Malcolm X], and a great many leaders of the Civil Rights’ Movement in the United States who stood firmly against racism and oppression for the cause of justice and human rights and the social progression of African peoples all over the world.

Civil Society, Human Rights, and Globalization: The demise of the continent's slow growth, heavy external debt, and state corruption had gone a long way by the tragic absence of the 1960s liberation mode and ethical commitments to the needy populations. African people were made to live in poverty-stricken situations that inhibited their access to the amenities and modern facilities. Poverty in Africa was a result of misguided development to increase wealth of the rich. The emphasis of the state on capital-intensive orientations, private land ownership, and large-scale mechanization, instead of labor-intensive traditions, community cooperatives and extended family systems, generated long-standing conflicts between peoples and governments, nomads and farmers, rural inhabitants and urbanites. Development disputes were often escalated into violent ethnic and regional feuds and/or political conflicts ensuing in huge losses of lives and property and violating gravely the rights of women and children (Bukuku \& Mahmoud, 1989:117-134).

The African civil societies became a popular force in the continent's striving to force a democratic path of development to protect the human rights. "There is now a very large and informal worldwide network of human rights NGO's, who exchange information about individuals' cases and patterns of violations. The two most developed organizations in this field are Amnesty International and the 'Americas Watch' organizations... many other organizations including national organizations make their own contribution” (MacDermot, 1989:50). “Within states, non-governmental organizations have multiplied during that period and governments are being forced to revise policies and laws that are offensive to basic human rights. At the continental level, NGOs and human rights advocates have demanded that the African Commission become part of this movement towards change. This is the lens through which Africans now view the African human rights system” (Mutua, 2000:38).

The Maputo Declaration issued by African Civil Society Organizations to the Second Summit of the Heads of States and Governments of the African Union, Maputo, Mozambique, 4th-12th July 2003 conveyed a strong critique of the continent's development: "We are deeply concerned about the continued imposition and adoption of neo-liberal policies that continue to impoverish the African people; the continued gross 
violation of human and economic rights especially in Zimbabwe, Swaziland, Liberia, Cote D'Ivoire, Burundi, Sudan, Uganda, Democratic Republic of Congo, Somalia, Nigeria, Western Sahara amongst others; the civil strife and armed conflict in the continent; the deteriorating terms of trade within the continent; lack of access, deterioration and privatization of basic social services such as water, energy, health and education; [and] the erosion/neglect of African cultural heritage.”

The NGOs Declaration raised a great outcry against "the ballooning levels of internal and external debt; the lack of political will to resolve the exploitation and mismanagement of natural resources in particular energy, water, minerals, flora and fauna and marine resources; and the plundering, mismanagement, removal of local resource management." The NGOs reechoed the long-standing struggles of the Continent to remove among other pandemics "and lack of benefit sharing, through inter alia biopiracy, promotion of genetically modified organisms and patents on life and life processes; lack of corporate accountability by transnational corporations; the HIV/AIDS pandemic and other diseases such as malaria, TB and its socioeconomic implications particularly for orphans and children and elderly in Africa; and the lack of collective and concrete actions to resolve the land issues in Africa” (Maputo Declaration, 2003).

The post-independence decades experienced widespread governmental paternalism that failed to transform the backward economies to efficient systems of production by rapid economic growth. A main reason for this failure was the negligence of many national and international development policy-makers to the African traditional economic, political, social and cultural realities. Contrary to the bureaucratic impositions and the paternalistic prescriptions of external sources, African indigenous orientations reinforced the integration of the social structure through cooperation, pluralism, collective bargaining, and compromise. These same value-orientations have been largely compatible with different forms of political pluralism, public freedoms, trade unionism, and international human rights’ norms (Bukuku \& Mahmoud, 1989).

In the current globalization epoch, African values "have been deteriorating as a result of interventionist policies and practices seeking to achieve rapid economic growth in terms of high rates of GDP by the adoption of large-scale mechanized agriculture, etc., at the expense of the indigenous social life” (Mahmoud, 2005:21-22). Because the negativities of African development were largely founded on the leadership failures to strike fair agreements with foreign investments in the service of the indigenous population, following sections touched upon the extent and volume of global investments in the continent. This was an indicator of the emptiness of African treasuries from essential priorities to ensure the public 
prosperity. Due to an uninterrupted process of depleting Africa from resources by profiteering economies via unprincipled national and external beneficiaries, the total dispossession of the indigenous living standards and resources led to unrelenting violence and civil wars. "Africa entered the twenty-first century saddled with ...brain drain... political violence, repression of human rights and the lack of a productive professional and technological environment” (Economic Commission for Africa, 2009:277).

The African NGOs and human rights' groups called on the African Heads of states and governments to "Recognize, engage, and utilize indigenous knowledge systems inherent and intrinsic to the poor and resides amongst them. This is as a means to involve the poor in social and economic upliftment processes by investing in them as a resource of development; Fight corruption and pursue good economic governance and make aid more responsive to development needs through the establishment of a joint civil society - government forum to engage donors and development partners; Respect the commitments made and agreed to, for the effective popular participation and promotion of human rights and democracy as enshrined in the international and national conventions; Develop democratic and autonomous local level institutions involved in land acquisition, allocation, conflict resolution and land management; Formulate natural resources management policies and legal frameworks that ensure improved access to land, forests, wildlife, water, fisheries and mineral resources by the rural communities” (Maputo Declaration, 2003).

The African NGOs and human rights' groups called on the African Heads of states and governments to "Recognize, engage, and utilize indigenous knowledge systems inherent and intrinsic to the poor and resides amongst them. This is as a means to involve the poor in social and economic upliftment processes by investing in them as a resource of development; Fight corruption and pursue good economic governance and make aid more responsive to development needs through the establishment of a joint civil society - government forum to engage donors and development partners; Respect the commitments made and agreed to, for the effective popular participation and promotion of human rights and democracy as enshrined in the international and national conventions; Develop democratic and autonomous local level institutions involved in land acquisition, allocation, conflict resolution and land management; Formulate natural resources management policies and legal frameworks that ensure improved access to land, forests, wildlife, water, fisheries and mineral resources by the rural communities” (Maputo Declaration, 2003).

Here, the socialist thinker Mohamed Ibrahim Nugud affirmed: "In the last three decades common legitimate claims crystallized [to apply] a) United Nations' resolution on the reduction of advanced nation's armament by a 
specific percentage of the revenue to assist the less developed countries; b) Exemption of the 20 poorest states of debt, and the search for better conditions of borrowing; c) Prohibition of the sale and export of arms to the 20 poorest states provided that the share of defense and security must not exceed a certain percentage of the GNP; d) Commitment of international capital to reinvest part of its profits in Third World Countries (TWCs); e) Commitment of international capital with increasing input of mid and advanced technology; [and] f) Commitment of international capital to train national caliber” (Nugud, 1997; cited in Mahmoud, 2007:215).

There was hardly a truer source than the UN's specialized agencies to provide evidence for this analysis: for one, the UN Conference on Trade and Development (UNCTAD) cautioned from "perceived risks and regulatory uncertainty in a fragile world economy... Flows to Africa...fell. At the same time, East and South-East Asia and Latin America experienced strong growth in foreign direct investment (FDI) inflows. New global forms of FDI include state-owned enterprises which indicate 'control' as well as 'ownership.' Investment liberalization and promotion remained the dominant element of recent investment policies (emphasis in the original). Nevertheless, the risk of investment protectionism has increased as restrictive investment measures and administrative procedures accumulated over the past years" (UNCTAD, 2013:XI).

In the processes of this globalization of world economies, Africa, as one of the "poorest regions," fell repeatedly prey to the hegemonic control and ownership of Multi-National Corporations via uninterrupted modes of foreign domination over African national or continental interests, asserted UNCTAD. "International production is expanding, with foreign sales, employment and assets of transnational corporations (TNCs) all increasing [emphasis in the original]: TNCs production worldwide generated valueadded of approximately \$16 trillion in 2010, about a quarter of global GDP. State-owned TNCs are an important emerging source of FDI. The ownership and governance of State-owned TNCs have raised concerns in some host countries regarding, among others, the level playing field and national security, with regulatory implications for the international expansion of these companies" (UNCTAD). The rapidly growing Middle-Eastern investors were closely involved in the whereabouts of this globalization of which a consequent section analyzed major aspects in Africa. It was therefore necessary to focus on the bureaucratic structures of the Gulf rich states that overwhelmed poor African states with prodigal finances.

\section{The Arab Governance and Bureaucratic Structures}

The success or failure of a state democratic performance (based on separate branches of government with competent legislative and executive 
bodies and independent judiciary) would have to be evaluated by an overall assessment of the structure, functioning, and performance of the state's bureaucracy (el-Kikhia, 1997). Additionally, there was a need to clarify the historical roots of the bureaucratic structure, the leadership and personnel issues, the law that governed state systems, and the response of the public that received and followed up with feedback on bureaucratic instructions. Few studies unraveled the complexities of this performance. The evaluation of bureaucratic structures was not solely based on the bureaucracy per se, whether it functioned under a dictatorship or a democracy. It was equally important to research the societal factors that influenced the bureaucratic process, the public mode, political awareness, and ethno-religious preferences. The societal factors, in their turn, influenced the roles that the public played to support the bureaucracy, democratize the performance, or ostracize the bureaucratic structure all together.

As of yet, the concern for public roles in the Arab States' centerregion dichotomy had not been intricately examined by democracy research; but the main strategies to control society were typically associated with the Arab Ruling Elite (ARE) manipulations of the state and business. Because the perfect bureaucracy existed only in the minds of philosophers, the performance of bureaucratic structures was never saved from failures or abuses of authority. The Gulf States restricted researchers from studying the government-citizen relationships; even formal information was hardly released to capture the extent to which a state could be favorable to people, judged by judicial and parliamentary competencies over executive performance. Thanks to a few independent works that applied professional and academic criteria, besides the International Internet which opened some blocked areas for millions of readers who were able to look into the views and criticisms of Gulf writers on the states and their internal affairs.

The Peninsula States constituted a genuine part of the Arab League. Ruling over large Muslim societies with ethno-tribal cultures, the power issues between the ARE and these structures were mostly based on the recognition of this reality. In modern times, the globalization of Arab societies, in general, and the Gulf States, in particular, brought to the surface dilemmas of modernity and the challenges of adjusting state bureaucracies to the moral values and social expectations of the Bedouin dominion. The dilemma of enhancing state-public relationships by non-democratic bureaucracies increased the challenges of political power in the midst of religious, cultural, and tribal pressures. "Autocratic regimes like those in Saudi Arabia, Kuwait, and the other Gulf States and Emirates found themselves exposed to assaults from so-called "progressive," though essentially not less authoritarian” (Rejwan, 1998:103). Still, the pursuit for a viable system of administration between central governments and regional 
locations developed a long-standing demand by democratic forces and civil society groups vis-à-vis the power monopolies of competing sheikhs or family-controlled parties.

In the post-independent decades of the Arab states in Africa and the Middle East, a nationalist model of the state was projected by growing civil society groups to process popular participation in decision making and development administration. In succeeding decades, the civic groups seldom secured organizational activities versus the ARE reluctance to ease the grip of power. In the meantime, socialist ideologies advocated progressive economic, political, and cultural programs to popularize the state by transitional governments whose popular programs were mockingly wiped out by succeeding single-party single-candidate systems of rule. Armed confrontations occurred between the ARE and contending groups. By the end of the Cold War Era, the public yearning to establish democratic secular states to implement necessary reforms on the center-region relations, to eradicate all forms of discrimination against the women, and to implement democratization agenda in the national sphere was forcibly oppressed by ARE alliances with anti-democratic conservatives and Jihadist groups. Thenceforth, the political conflict was polarized by the striving of Jihadist forces to seize the state power in their own right, regardless of former alliances with the ARE.

In the 2000 decades, the Gulf conservativeness was actively manipulated in varying degrees by the Muslim Brotherhood and Salafi Jihadist militant groups: "As a result, governments in Bahrain and Kuwait have tended to treat Salafi groups similarly to the way they deal with the Muslim Brotherhood. In Qatar and the UAE, Brotherhood and Salafi branches exert influence on government policymaking, particularly in the social realm, through informal means or through government granted bureaucratic posts. Because these states lack legislative elections, policymaking remains centralized, leading rulers either to attempt to co-opt or crack down on independent political and social movements... even on informal Islamist activity, while the Qatari government has historically been more receptive to Islamist complaints in the realm of social policies and allows Islamists to remain working within the bureaucracy” (Freer, 2016:1).

Pursuing national interests with opposition groups, nonetheless, the emerging civil societies acted patiently towards the ARE leaderships, which hardly insured equal political or economic benefits to the rural people or recognized the right of urban communities to enjoy equal representation in the national decision-making. This attitude differentiated the Gulf curbed formulations from the liberality of the African confrontationist societies. Academic investigation confirmed that "civic organizations in Qatar represent traditional, non-democratic forms of societal involvement - 
opportunities to build broader connections, to have a life outside the home, but not opportunities to learn about and experience democratic politics or to mobilize support for particular policies....Civic participation on its own will not lead Qataris toward more democratic orientations such as political trust, social tolerance or support for a democratic political system. It is precisely those who least value and least understand democracy - and who most benefit from the political status quo - that tend to be most actively involved in civil society" (Gengler et al, 2011)

A clearer portrayal of change appeared in this analysis: "globalization patterns add a potentially destabilizing dimension to the interdependencies that have long bound the Gulf States to the international community. Increasingly these new linkages bypass state structures and control and constitute both an ideational and material threat to their politics” (Ulrichsen: 2015:1-2). Stressing the "inequalities and security challenges" in Bahrain, Saudi Arabia, Oman, UAE, and Qatar in the Gulf post-oil era, the 2011 Arab Spring's “civil uprisings shook the political economy of authoritarian state structures across the Arab world... states in transition are more vulnerable to predatory political violence and challenges to regime legitimacy." The political economy of Egypt and Tunisia uprisings was evident in the Gulf States, including "bulging young populations, high youth unemployment and unbalanced labor markets, and authoritarian regimes reluctant to open up to meaningful political reform. An example is unemployment among Saudi nationals between the ages 20-24, which was a reported 38.4 per cent in 2008, with the figure rising to 72 per cent for women alone” (Ulrichsen, 2015:180).

The Human Rights' Situation: As in Africa, the excessive centralization of power failed to place the needs of rural population as the chief agenda of development administration. The politics of development ascertained in most Arab societies the same trend of exclusionary policies towards the civil society, the Kurds, Berbers, Nubians, Shiite, and Christian minorities, and the African and Asian emigrants. The dispute between state bureaucracies and popular movements was escalated by suppression of the public freedoms, which disabled democratic growth and even development. It also gave rise to prevailing religious intolerance, as well as irreconcilable confrontations between independent liberal oppositions and the state coalitions with Jihadist groups. The ARE security actions to restrain labor unions and professional associations exacerbated hostilities of the rural leaderships that inevitably joined the urbanite struggles for equity and human rights.

The report on Qatar 2016 human rights showed that "The principal human rights problems were the inability of citizens to choose their government in free and fair periodic elections, restriction of fundamental 
civil liberties, and denial of the rights of foreign workers. The monarchappointed government prohibited organized political parties and restricted civil liberties, including freedoms of speech, press, and assembly and access to a fair trial for persons held under the Protection of Society Law and the Combating Terrorism Law. Other continuing human rights concerns included restrictions on the freedoms of religion and movement, since migrant workers could not freely travel abroad. Legal, institutional, and cultural discrimination against women limited their participation in society. Trafficking in persons, primarily in the domestic worker and labor sectors, was a continuing problem. The noncitizen "bidoon" (stateless persons) who resided in the country with unresolved legal status experienced social discrimination. The government took limited steps to prosecute those who committed abuses” (U.S. Department of State, 2016:1).

The Saudi Arabia 2015 Human Rights Report stated that "The most important human rights problems reported included citizens' lack of the ability and legal means to choose their government; restrictions on universal rights, such as freedom of expression, including on the internet, and the freedoms of assembly, association, movement, and religion; and pervasive gender discrimination and lack of equal rights that affected all aspects of women's lives. Other human rights problems reported included a lack of equal rights for children and noncitizen workers; abuses of detainees; overcrowding in prisons and detention centers; a lack of judicial independence and transparency that manifested itself in denial of due process and arbitrary arrest and detention; investigating, detaining, prosecuting, and sentencing lawyers, human rights activists, and antigovernment reformists; holding political prisoners; and arbitrary interference with privacy, home, and correspondence. Violence against women; trafficking in persons; and discrimination based on gender, religion, sect, race, and ethnicity, as well as a lack of equal rights for children and noncitizen workers were common. Lack of governmental transparency and access made it difficult to assess the magnitude of many reported human rights problems.” (U. S. Department of State, 2016:1).

In the Human Rights Report 2016 of the United Arab Emirates: "The following human rights problems exist or were reported: no citizens' right to change the government and no popularly elected representatives of any kind; flogging as judicially sanctioned punishment; arbitrary detention; incommunicado detention permitted by law; questionable independence of the judiciary; restrictions on civil liberties--freedom of speech and of the press, and assembly; restrictions on right of association, particularly for human rights groups; restrictions on religious freedom; domestic abuse of women, sometimes enabled by police; trafficking in women and children; legal and societal discrimination 
against women and noncitizens; corruption and lack of government transparency; abuse of foreign domestic servants; restrictions on and abuses of workers' rights. The government has made steady progress in addressing the problem of trafficking of women in the sex trade and children in the camel racing industry. In July, the government enacted a law, immediately enforceable, criminalizing the participation of children under age 18 in camel racing... In December, President Khalifa announced, and the Supreme Ruling Council endorsed, a decision to indirectly elect half of the consultative FNC” (U.S. Department of State. 2016).

"Gulf countries saw their already low press freedom index rankings slip further in 2016, in a report put together by media watchdog group Reporters Without Borders (RWB). Journalists in the Gulf continued to work in a stifling environment of censorship, where authorities often intervene directly or indirectly in their work. Saudi Arabia had the worst record for press freedoms in the Gulf region, which saw their ranking slip one place to 165 in the world. In comparison, Mauritania - at rank 48 - had the [freest] press in the Arab world. Near the bottom of the rankings was Syria at 177, where an active rebellion against a brutal dictatorial regime is ongoing and has seen it retain the title of worst press freedoms in the Arab world. Despite a change of administration, Saudi Arabia continues to have one of the most restricted media environments in the world, a Freedom House report said this year. Although social media has provided a conduit for access to news "it too is being suppressed as the government seeks to silence criticism of its domestic policies and its war in Yemen". Writers and activists critical of the Saudi government or who cover sensitive subjects such as Islam continue to face harsh punitive measures... The remaining Gulf Arab countries were ranked 103 (Kuwait), 117 (Qatar), 119 (UAE), Oman (125) and 162 (Bahrain)” (TheNewArab, 2016).

To conclude, the curtailment of the minimum standards of public freedoms and human rights was a key factor of the ARE's rejection of the public scrutiny of the disproportionate share of poor urbanites and rural people in the centralized administrations, the fountainhead of the crisis. This exclusion enforced protracted exploitation of the peripheries; the rural women were victimized by illiteracy, unpaid domestic labor, and multiple forms of discrimination; and the ARE/Jihadists' negligence of even development became a prime mover of political resistance. A longstanding leadership cult in both African and Arab states (Siciolino, 1991; Ottaway, 1998) escalated the turbulence by contradictory manipulations of religious laws and traditional cultures (Lapidus, 2002; Halliday, 2003; Hafez, 2003). The tragedy of this crisis was manifested in the ongoing civil wars of Syria, Iraq, Sudan, Libya, and the expanding Saudi-Yemeni warfare which might well spread over the vulnerable Gulf. 
The Center-Region Perplex: As experienced in African states, tribalism, ethnicity, and regional alliances were intensively influenced in the Arab Peninsula by partisan motives. "The most common internal candidate for the specificity of the Middle East is, of course, Islam, but Arabism and tribal forms have also been cited," asserted Bromley (1994:87). In addition to rivalries on the leadership of the Muslim world, internal instability correlated with unsettled political struggle. The center-region conflict introduced Iran as an external player in the Arab region. The fear of Iran expansionism escalated unrestrained war over every inch of the land between the Houthi/Salih forces and a Saudi alliance, which almost destroyed the entire country and civil life, with the post-Salih elected government, the Gulf Cooperation Council (GCC), and western powers: “a proxy war, the stage in which Saudi Arabia tries to consolidate itself and fight Iran... exacting a terrible humanitarian cost with serious implications for regional stability. American, British, Canadian and French support for the operation continues, much to the outrage of human rights organizations worldwide" (Mijares, 2017) "Roughly 10,000 people, including some 4,100 civilians, have died, 3.2 million people (12 percent of the population) have been displaced, pestilence (in the form of Cholera) has hit the capital, and famine approaches, with more than half the population food insecure” (Bandow, 2017).

The touches of modernity with the region since colonial times did not ripen sustainable forms of democratic rule or even stable peace; and the drafting forms of bureaucratic recruitment by the Jihadist councils and/or state-financed businesses failed to function as replacements of modern parliamentary rule. In Qatar and Bahrain, the government agencies sided with the Jihadists and placed the civil society, the Sufi and secular thought under police surveillance. The crisis of non-democratic rule in the region was thus a crisis of both society and state. "Nearly every Arab state today has avoided the clear dichotomies of choice - such as religious versus secular in forging their political-cultural identities... each Arab state (or regime) has attempted its own reconciliation with great emphasis on one particular dimension but never to the total exclusion of the other" (Ibrahim, 1996:246). This analysis was evidently felt in the GCC defense of Qatar vis-à-vis Egypt's mention of visits to Qatar by a Jihadist who blasted the Copts' cathedral in Cairo (Alarabiya, 2016; Veto, 2016). Contrariwise, "a conference of local and international civil society organizations was hosted in Dubai on the role of civil society in the Arab Region in implementing 2030 agenda for sustainable development” (Gulf Times, 2016).

Ironically, the sponsored militancy that aimed to establish theocratic rule in the targeted societies undermined the ARE plans to democratize the sponsoring state. As the interventionist actions backfired, the ARE was 
forced to sabotage the political awareness of their own countrymen about the Jihadist antagonisms that disturbed the social life and worsened the marginality of minorities. A possible seizure of political power by theocratic organizations escalated the ARE fear for loss of power. The ARE were thus caught in the middle of the conflict, which resulted in gross violations against the lives and property of political opponents. The Jihadist militias in the post-Qaddafi Libya, post-Mubarak Egypt, Bashar allies in Syria, and Bashir security forces in Sudan provided stunning examples of this disruption which amounted to street wars in cities and the house-to-house bombing of children and women, the most appalling victimology of war.

The striving of Saudi Arabia to enhance decentralization, "will be a complicated challenge to move both toward centralization and decentralization at the same time," predicted Dahlan (1990:61). The first Saudi Shura Council was established in 1924. "The council consisted of twelve members. At that time, when the state structure was not completed, the council was entrusted with drafting the basic laws for the administration of the country... there was no law to specify the functions of the council. However, that council continued for six months. After the Kingdom achieved enormous progress in development, the Custodian of the Two Holy Mosques, the late King Fahd bin Abdul-Aziz introduced three major laws: the Basic Law of Governance, the Provincial Councils' Law, and the Majlis Ash-Shura Law. The modernization of Majlis Ash-Shura was considered to be [an] update to what had already existed by enhancing the council's frameworks, methods, and means and injecting efficiency, organization, and vitality into them... In the fourth term, the council consisted of a speaker and 150 members, representing people of knowledge, experience, and competence” (The Shura Council, 2016).

"In December [2015] the country held elections on a nonparty basis for two-thirds of the 2,106 seats on the 284 municipal councils around the country. Independent polling station observers identified no significant irregularities with the election. For the first time, women were allowed to vote and run as candidates. Civilian authorities generally maintained effective control over the security forces” (U.S. Department of State, 2016). Some critics wrote about the decision of the Council to increase the salaries of retired military ranks. Several commentators complained from bureaucratic routine and indicated dissatisfaction for the biased selectivity of the Council's decisions and the one or two years' negligence of appeals to increase salaries for other employees of the state in "a time of price-rise and a very big change of living conditions.” ARE transformed the administrative and financial systems to a tool in the service of personal interests to suppress the lower echelons of the bureaucracy, the indigenous farmers and workers, 
and the expatriates’ wage-labor, Internet free-lance Gulf writers claimed (Hawamir alBorasa Alsoudiya, 2016).

The human rights' performance in many African and Arab states discredited them from the high-esteemed membership of the United Nations Human Rights' Council (UNHRC), overseer of the member States' commitments to human rights and protector of the international norms. "As the U.N. prepares to elect 14 nations to its highest human rights body, a 21page joint NGO report was published by UN Watch, Human Rights Foundation and the Raoul Wallenberg Center for Human Rights. The findings were that China, Cuba, Russia, Saudi Arabia, Egypt, Iraq, Malaysia and Rwanda, are “Not Qualified” under the U.N.’s own membership criteria. The qualifications of Guatemala, South Africa and Tunisia were deemed "questionable" based on problematic human right records or in their UN voting records” (UN Watch, 2016).

An overall comparison on the structures and policies that governed the post-colonial African and Arab states indicated they were founded by oppressive power relations that alienated the ruling elites from the ruled citizens, and offered disproportionate access to the national resources for abusive businesses and external investors. Regardless of differences between legislative elections and civic experiences in African states, compared to poor experiences in the Gulf, the post-independence governments inhibited liberal political groups and civil society associations from national decisionmaking. In the absence of popular leaderships strongly committed to people, the Arab and the African states failed to handle the center-periphery democratic governance. Mindful of these commonalities, the next section analyzed major aspects of the businesses that boomed in the present time between the Gulf expanding investment in the lands, minerals, and labor of Africa and the poor African economies and autocratic regimes, commissioners of the new sponsors.

\section{The Gulf investments in Africa}

Mirna Sleiman (2013) noted that "wealthy Gulf Arab companies are boosting their investment in Africa's vast lands and untapped resources." Affirming positive motives "including Africa fast economic growth, the rise of a free-spending African middle class, and a sense that much of the continent is becoming better government and more stable politically... Africa is a source of food and arable land, and it is launching an infrastructure building boom that recalls the Gulf's own construction spree in the past decade." The writer then emphasized that "Africa is becoming more interesting because of the natural resources it has, its demographics and better governance” (Reuters, 2013). 
This auspicious evaluation by Gulf investors did not overlap with realities of the African socio-political and economic life. What appeared factual were the UNCTAD bare facts about non-equity investments in the poorest regions of the world that supplied huge surpluses to the investing firms' vis-à-vis African states and private businesses. Moreover, "The Middle East's oil exporters posted a combined surplus in goods and services of about $\$ 400$ billion last year [2012], the International Monetary Fund estimates. Much of that money is being ploughed back into foreign assets; while the bulk still goes into Western assets such as U.S Treasury bonds, more is going to emerging markets such as Africa. Annual trade between the Middle East and Africa has grown fivefold to \$49 billion over the past decade, from \$10 billion in 2002, according to Standard Chartered Bank" (Seliman, 2013).

Linguistic, cultural and political ties centered the Gulf investment in North Africa. "Increasingly, Gulf investors are venturing into sub-Saharan Africa. Dubai port now runs the port of Dakar in Senegal and port operations in Mozambique, Algeria and Djibouti. In addition to Egypt and Nigeria, [UAE] Etisalat operates in about six countries in West Africa, as well as Tanzania and Sudan. [Despite these monopolies and profits, a complaint by Eitsalat chief executive says] the record of its African investments has not so far been impressive, partly because of fierce competition from other operators... Saudi Arabia and Qatar have been buying large areas of farmland overseas to ensure access to food supplies. Qatar's Hassad Food agreed in 2009 on a $\$ 1$ billion farmland development joint venture with the government of Sudan” (Seliman, 2013). "The state and Saudi business concerns have already made a combined investment of more than $\$ 11 \mathrm{bn}$ in agricultural ventures across a number of countries, including Brazil, Canada, Ukraine, Ethiopia and Sudan” (Oxford Business Group, 2013).

A "risk involving Gulf States in the socio-political and water scarcity problems of African countries, if they displace local people from their land or disrupt local farming patterns" (Oxford Business Group, 2013) voiced loudly in the continent from many farming groups. The investors were quite insensitive to the culture and value-orientations of the natives. As a Gulf top executive put it, "We like to invest in commodities. Since 2002, the commodity price trend keeps going up. May be 2016 and 2017 might create a gap between supply and demand that might push the price even higher up. Our strategy is simple: we are opportunistic... If there is an opportunity in Rwanda, we will go to Rwanda,” said Hussain al-Abdulla, Qatar Investment Authority (QIA's) executive board member (Regan Doherty, 2012).

For many observers, the newcomer investors resembled an effective successor of the colonial models that suppressed the popular demands to maintain private gain - in both cases nothing was felt by the broader public 
as improvements in the workaday life or the future. While Zimbabwe redistributed land ownership to allow decent life to the bulk population, the farmers of the public-owned giant Gazira Agricultural Scheme in Sudan were stripped of the Scheme's contractual rights by privatization projects. The railways, civil and agricultural engineering structures, ginning mills, and research centers were liquidated without fair consultations with or compensations to the farmers as a founding partner (Agricultural Engineers' Group, 2009:9; SHRO Taayush, 2009:16). The government ventured with "The International Islamic Movement represented by Turkish, Iranian, Egyptian, and other companies... 59\% of the Gazira and Manaqil stateowned areas that the government intended to sell to the Islamist investors had been registered for farmers since eighty years ago" (International Campaign to Defend the Gazira and Manaqil, 2011:186).

The popular resistance to "land acquisitions by foreigners" was a clear reflection of the FDI/TNC domination of the industrial, oil, agricultural, and service sectors of the national economies. The bragging statements of finance and agriculture officials in several African states about "opportunistic business" by lucrative deals for a promising coverage of food and employment were belied by violent demonstrations in the streets of Nairobi, Cairo, Khartoum, and many cities protesting steeping scarcity of food and job opportunities at their end. Popular uprisings in Africa and the Middle East and similar movements in Brazil and Latin America exercised immense protests against deterioration of the public life, the high rates of unemployment, expatriation, brain drain, and financial corruption of the state - all were concrete symptoms of the morbid financial and economic policies of the ruling leaderships of the globalized systems.

Interestingly, these disturbing businesses entailed further expanded frustrations in diplomatic terms. Years ago, Qatar made a pro-government political endeavor, sidelining the Sudanese democratic opposition, the African Union, and the sisterly neighborhoods of Sudan, namely Egypt and the IGAD, to resolve the Darfur crisis by sponsoring direct negotiations between Darfuri rebel groups and the Sudanese government under a hefty promise Qatar would contribute a billion dollar or so to rehabilitate Darfur. Neither the Qatari diplomacy nor her promised money ended the crisis which would only be solved by a national constitutional conference for all democratic forces of the country, Sudan government, AU, the UN, and the concerned regional and international powers to put to task the required transition to permanent peace and democratic rule.

A most recent interruption of the Saudi-Egyptian cooperation was negatively linked to irreconcilable political differences between the two countries concerning a Saudi resolution to settle the Syrian crisis before the UN Security Council versus a competing Russian resolution that Egypt 
supported, instead of the Saudi expectation. Qatar and Saudi criticized Egypt's Vote (RT, 2016). The suspension of Saudi petroleum products to Egypt was then media-linked to the Security Council's tensions (Orient Net, 2016). "The two countries do not have the same priorities: the kingdom is mainly worried about the Iranian menace, while Egypt is bogged down in its war against terrorism in the Sinaï and against ISIS in Libya. And yet there is much to unite them, in particular their hostility towards the "Arab spring" and their commitment to regional "stability." Thus they co-operate on the Palestinian question and also, more discreetly, work together to counter Iranian influence in the Horn of Africa, and particularly in Eritrea and Sudan. These maneuvers resulted in Khartoum and Teheran breaking off diplomatic relations earlier this year" Gresh (2016). Egypt's "hostility towards the Arab spring," nevertheless, was quite the opposite as the new government of Egypt was one of the major outcomes of the Arab spring.

Sudan was actively engaged in large-scale investments with the Gulf businesses, in addition to bulky monetary dealings with the governments of Iran, China, and Turkey, including arms’ industry and shipments (Iran News Update, 2014). The non-censored deals elevated corruption of the government (ranking 173 of the 176 countries that International Transparency reported) and escalated further the ruling party's acts of repression against the opposition to unprecedented levels of violence. Civil wars escalated in almost all parts of the country leading to the full separation of South Sudan, which engaged in a bitter Dinka-Nuer tribal armed striving for power, and alienated further the diverse population of the country by the center's demagogic indoctrination. Of the worst, the war-mongering policies of the Jihadist regime expanded civil wars in its own territory; and then moved hurriedly to engage the Sudanese armed forces in military action in Yemen - a country having a long history of sisterly non-interventionist ties with Sudan. Yemen has been lately facing a politically motivated civil war, as Sudan itself suffered for decades with everlasting failure to make peace via military action.

"The Sudanese government plans to transform the Nile, the only stretch of fertile land north of Khartoum, into a string of five reservoirs. Built by Chinese, German and French companies, the Merowe Dam was completed two years ago. The project doubled Sudan's electricity generation, but displaced more than 50,000 people from the Nile Valley to arid desert locations. Thousands of people who refused to leave their homes were flushed out by the reservoir, and protests were violently suppressed... In 2007, China also voted in favor of the Declaration on the Rights of Indigenous Peoples at the UN. This document stipulates that indigenous peoples have the right of consent regarding "any project affecting their lands. The Kajbar Dam, which is strongly opposed by the indigenous Nubian 
population, violates the UN Declaration" (Bosshard, 2000). "In 2010, the Sudanese government awarded a $\$ 705$ million, five-year contract to build the Kajbar Dam to the Chinese company Sinohydro, the world's largest hydropower contractor. The affected communities and International Rivers have called on Sinohydro to withdraw from the Kajbar contract" (International Rivers, 2000).

"Sudan and Saudi Arabia signed agreements on the finalizing of the Kajbar, Dal and El Shireig dams in northern Sudan and the cultivation of a million acres of farmland near Atbara... In July and August, the Central Bank of Sudan received a total of \$1 billion from Saudi Arabia” (Dabanga, 2015). In the African water-abundant Nile land, the Saudis paid \$1,000 an acre. In Southern California, they purchased an acre for $\$ 17,000$, and paid almost $\$ 5,000$ for an acre of "scarcely populated" water-disputable land in Arizona (Los Angeles Times, 2017). The Merowe and the Kajbar multibillion dollar dams were publicly disputed against loss of land and destruction of heritage by the Manasir and Nubian people, as well as environmentalist researchers: "The Kajbar and Dal projects are located in the lands of ancient Nubia. After large Nubian territories have already been lost to the reservoir of the Aswan Dam, construction of these new dams would bring the unique Nubian culture, which dates back over more than 5,000 years, closer to extinction. The affected people are strongly opposed to the construction of the Kajbar and Dal dams. They have warned that the projects could lead to a second Darfur conflict. The Sudanese government has cracked down harshly on their protests" (International Rivers, 2010).

"On June 13, 2007...The protesters marched to the dam site to protest; after being hit by heavy tear gas, all of a sudden, live bullets were fired and Sid-Ahmed was the first victim to fall to the ground... 'The agreement is on paper, but the reality is we have not been compensated for our land. We want to be resettled around the lake, but the government wants to resettle us far away,' said Al-Rashid Al-Affendi, of the Executive Committee of the Manasir People Affected by the Merowe Dam, in an interview with Al-Monitor" (Reem Abbas, 2013). "In 2007, security forces killed four and injured at least 20 people who protested peacefully against the proposed Kajbar Dam. The UN Special Rapporteur on Sudan deplored the excessive force used against the Nubian population" (International Rivers, 2010). In 2013, the government "found considerable gold seams in the northern states... Sites of archeological importance were destroyed and high levels of cyanide and mercury found dumped during the extraction process... in the past five years Nubians in Kajbar have been losing their [palm] trees in suspicious circumstances. The Anti-Kajbar committee says that about 200,000 trees have been destroyed” (The Guardian, 2014). 
In Tanzania and Ethiopia the negativity of foreign investments undermined the pharmaceutical local manufacturing by displacement strategies imposed largely upon the national markets, despite improvements in industry. "By 2009, Tanzania-based production was supplying an estimated $35 \%$ of a local medicines market worth about US\$140 million, and rising medicines exports had reached almost US\$8 million. A particular strength of the local firms was supply to the rural areas. In 2009, Tanzanian pharmaceutical production looked like a relative success story. Yet between 2009 and 2013, this success story turned into rapid decline. By 2013, imports of pharmaceuticals had risen to US\$286 million on the back of rising donor spending, while medicines exports had fallen to US\$1.7 million. Donors such as the Global Fund procure a large share of medicines used in Tanzania. Their large scale tenders and the market entry requirement of product-byproduct WHO prequalification shuts out local firms from markets for HIV, TB and malaria drugs” (Tibandebage et al, 2016:42-52).

Similar investments in Africa were detrimental to the African wellbeing and healthy production relations. United Arab Emirates and China reaped large investments in the pharmaceutical industry of Ethiopia. Even with achievements in the size, capacity, and quality of products, "there are outstanding issues to be addressed such as the low production capacity and overwhelming dependence on importation of medicines; shortage of qualified management and technical personnel; and inadequate continuing professional development for practicing professionals; conflicts of interest with the suppliers of raw materials in India and China (as they are producers of medicines, so they charge higher prices); ... low manufacturing capacity and hence high production cost" (Gebre-Mariam et al, 2016:82-83).

Recent analysis of Qatar's investment diplomacy in Africa revealed that "Qatar wanted to exist geopolitically, mainly but not solely, vis-à-vis the Saudi neighbor... Qatar is achieving its objectives via its investment fund, Qatar Investment Authority, and its Al Jazeera news channel, but also through opening embassies on the five continents and developing Qatar Airway's routes” (Benjamin Augé (2016:9). This study found "Qatar and the African countries are two worlds unfamiliar with each other... Relations are no longer straightforward between ambassadors from the African continent and the Qatari Ministry of Foreign Affairs... it was sometimes extremely difficult to meet key people in institutions or Qatari ministries in Doha... Although it is easy to find North American or European specialists at the Ministry, African specialists are still very much lacking, and they appear as the poor relation of Qatari diplomacy, which admittedly, still has not really specified the goals to be achieved on the African continent."

Augé study concluded in the fact that "the lack of qualified civil servants and experts on Africa explains the relative lack of vision about an 
area which Qatar could interact with more. The lack of risk-taking in terms of Qatari investments in Africa frequently highlights the lack of time and native staff to review the projects... The economic sectors, such as gas, oil, mining, banking, and agriculture are only subject to profitability. The security of food supplies is also a very important focus of the country." The writer then advised, "The mediations that the country has undertaken alone, involving among others Darfur, have achieved rather mixed results, since it is not acceptable to pay the parties to achieve peace, a long-term process should be considered. Political partnerships are also to be looked for on the side of the major African powers, like South Africa and Nigeria, in order to facilitate discussions on conflicts and to find a common solution” (Augé, 2016:25-26).

Structural Defaults: Pointing to Asian investment strategies in Africa, especially China whose thirst to the black gold of Africa swept undoubtedly over the Communists' socialist values, "We may continue to depict as foreign, the capital of some TWCs such as China, Malaysia, and the Arab Peninsula... capital globalization is seen in the hegemony of multinational corporations... International capital is a necessary development element. The question is, under what conditions: mutual benefit or exploitation of the economic surplus under the innovated term of Interdependence” (Mohamed Ibrahim Nugud, 1997; cited in Mahmoud, 2007:212-3). The ongoing transactions generated lion shares to foreign investments via African commissioners in the public and the private sectors, while a few mutual benefits accrued to the public life often for interests of the ruling elites

Yes, sections of the middle classes obtained some profits from shared ventures with foreign businesses, mostly through government bank loans and subsidies. This minimum was syphoned off to process development projects for political propaganda, including rigged elections. The alternative of this narrow-focused development might be logically developed into plans of action towards the achievement of equalitarian, productive, and most popularly oriented bonds. The prosperity of the middle class sections was more of a parasitic type of investment than real increases in the production inputs, means of production, or even increases in shareholdings with the foreign investor. The latter, unlike national investors, was fully protected from state taxation, shielded by international agreements, and motivated to profit, own, and control indigenous people and land. What else but neocolonialism!

These policies scrapped the local entrepreneur and surrendered the national economies to a strong presence of foreign non-equalitarian relationships, which abused the continent's resources, the unquestionable benefits of the African people. Africa revenues were deeply depleted by 
external debt stocks and service: according to World Bank Statistics (2011), in Angola, for example, external debt stocks, public and publicly guaranteed (PPG) increased in billions of current US\$ from 1.9 in 2008 to 2.0 in 2011. The total debt service decreased slightly in Kenya, Mauritius, Mali, Uganda, Zambia, and Algeria; but the debt service increased in Malawi (US\$1.926 billion, equivalent to 54\% of GDP, compared to 33.6 of GDP in 2011); Angola (1.4 to 4.2); and Egypt (5.6 to 7.4) with the same trend in Mauritania, Mozambique, Sudan, and Tunisia.

UNCTAD (2013) asserted, "In today's world, policies aimed at improving the integration of developing economies into global value chains must look beyond FDI and trade [emphasis in the original]. Policymakers need to consider non-equity modes (NEMs) of international production, such as contract manufacturing... and other types of contractual relationship through which TNCs coordinate the activities of host country firms, without owning a stake in those firms... It is evident that 'Cross-border NEM activity worldwide... is estimated to have generated over \$2 trillion of sales in 2009. Contract manufacturing and services outsourcing accounted for \$1.1-1.3 trillion, franchising \$330-350 billion, licensing $\$ 340-360$ billion, and management contracts around $\$ 100$ billion. In most cases, NEMs are growing more rapidly than the industries in which they operate” (UNCTAD, 2013:XII).

The UN report recognized the fact that "NEMs also pose risks for developing countries [emphasis in the original]." Employment in contract manufacturing could be highly cyclical and easily displaced. The value added contribution of NEMs might appear low if assessed in terms of the value captured out of the total global value chain. Concerns existed that TNCs might use NEMs to circumvent social and environmental standards. And to ensure success in long-term industrial development, developing countries needed to mitigate the risk of remaining locked into low-valueadded activities and becoming overly dependent on TNC-owned technologies and TNC-governed global value chains (UNCTAD, 2013).

Seized by this global eminence with its vehemence to expand, overrun, and dominate by dependency policies the African development potentialities and prerogatives, as well as those of the "poorest countries" (irrespective of the material and moral obligations conferred on all nations by international human rights' norms, besides the national and continental popular conditionality of processing these key transactions democratically), there was little doubt that corruption control would not be effectively enforced, as clearly documented by international transparency reports. African countries transparency reports indicated the prevalent corruption in African state bureaucracies. The Country Rank of 176 countries revealed that budget openness was scant or none with low scores, except for very few 
countries, for example Tunisia, Uganda, Kenya, Madagascar, and Egypt. The majority of African countries maintained high financial corruption as they occupied in the top ranks the lowest scores amongst the total reported countries in the world (Table One).

Table One

African Countries Transparency Indicators

\begin{tabular}{|c|c|c|c|c|c|}
\hline Country & Rank & Score & $\begin{array}{l}\text { GDP L } \\
\text { US\$b }\end{array}$ & Literacyo & $\%$ IMR \\
\hline Rwanda & 50 & 53 & 5.63 & 70.7 & 59.1 \\
\hline Liberia & 75 & 41 & $986.2 \mathrm{~m}$ & 59.1 & 73.6 \\
\hline Tunisia & 75 & 41 & 44.29 & 77.6 & 13.8 \\
\hline Burkina F. & 83 & 38 & 8.82 & 8.7 & 92.6 \\
\hline Morocco & 88 & 37 & 90.8 & 56.1 & 30.4 \\
\hline Zambia & 88 & 37 & 16.19 & 70.9 & 68.9 \\
\hline Senegal & 94 & 36 & 12.95 & & 49.8 \\
\hline Djibouti & 94 & 36 & 1.05 & & 73 \\
\hline \multicolumn{2}{|l|}{ Tanzania 102} & 35 & 23.06 & 72.9 & 50 \\
\hline Algeria & \multirow{2}{*}{105} & \multirow{2}{*}{$\begin{array}{l}34 \\
34\end{array}$} & 159.43 & 72.6 & 30.5 \\
\hline Mali & & & 9.25 & 26.2 & 99.2 \\
\hline Ethiopia & 113 & 33 & 82.90 & 29.8 & 67.8 \\
\hline Egypt & 118 & 32 & 218.89 & 66.4 & 18.6 \\
\hline Madagas & 118 & 32 & 8.72 & 64.5 & 43.1 \\
\hline Sierra Leo & о 123 & 31 & 1.91 & & 40.9 \\
\hline Mauritani & nia 123 & 31 & 3.64 & \multirow{3}{*}{$\begin{array}{c}5 / .5 \\
55.1 \\
56\end{array}$} & \multirow{3}{*}{$\begin{array}{c}75 . \\
92.2 \\
66\end{array}$} \\
\hline Mozambiq & iq 123 & \multirow{2}{*}{$\begin{array}{c}31 \\
30\end{array}$} & \multirow{2}{*}{$\begin{array}{c}9.59 \\
3.15\end{array}$} & & \\
\hline Togo & 128 & & & & \\
\hline Uganda & 130 & 29 & 17.01 & 73.2 & 63 \\
\hline Kenya & 139 & 27 & 31.41 & 87 & 55.1 \\
\hline Nigeria & 139 & 27 & 193.67 & 60.8 & 88.4 \\
\hline Cameroon & 144 & 26 & 22.39 & 70.7 & 84.4 \\
\hline Eritrea & 150 & 25 & 2.12 & 66.6 & 42.3 \\
\hline Guinea-Bi & 3is 150 & 25 & $878.52 n$ & & 92 \\
\hline Guinea & 154 & & 4.51 & 39.5 & 81.2 \\
\hline Angola & 157 & 22 & 114.2 & 70 & 97.9 \\
\hline Libya & 160 & 21 & 62.36 & 88.9 & 13.4 \\
\hline Dem.Cong & 160 & 21 & 13.15 & 67 & 111.7 \\
\hline Zimbabw & 163 & 20 & 7.47 & 91 & 50.9 \\
\hline Chad & 165 & 19 & 7.59 & 33.6 & 98.9 \\
\hline Burundi & 165 & 19 & 1.61 & 66.6 & 87.8 \\
\hline Sudan & 173 & 13 & 62.05 & 86.7 & 70.2 \\
\hline Somalia & 174 & 8 & $917 \mathrm{~m}$ & & 108.3 \\
\hline
\end{tabular}

(Source: Financial Transparency Reports, 2012; author's construction)

Table Two

Middle-Eastern Countries Transparency Indicators

$\begin{array}{ccccc}\text { Country Rank Score } & \text { GDP } & \text { Literacy } & \text { IMR } & \text { Corruption } \\ \text { US\$b } & \% & & \text { Percentile\% }\end{array}$

$\begin{array}{lllrlrl}\text { Saudi } & 66 & 44 & 434.57 & 86.1 & 15 & 62 \\ \text { Qatar } & 27 & 68 & 98.31 & 94.7 & 6.7 & 91 \\ \text { UAE } & 27 & 68 & 297.65 & 90 & 6.1 & 80\end{array}$

(Source: Financial Transparency Reports, 2012; author's construction) 
To compare to the investing Middle-Eastern States, Table Two on Saudi, Qatar, and UAE scores indicated a big gap in the rates of corruption control between the sending nations and the recipient African states. The Control of Corruption Rank percentile \% in African countries (average less than $40 \%$, as mentioned in the ITR, 2012) was incomparable with those of Qatar (91\%), UAE (80\%), and Saudi (62\%). “A country’s or territory’s score indicates the perceived level of public sector corruption on a scale of 0 - 100, where 0 means that a country is perceived as highly corrupt and 100 means it is perceived as very clean. A country's rank indicates its position relative to the other countries and territories included in the index" (Transparency International, 2012).

To sum up, capitalism's opponents envisioned foreign investment as inhibitions of sustainable development in the TWCs which had already begun to embrace geographical expansion of capitalist investments in the remaining pre-capitalist formations and the traditional sector, where most of the population lived with the reservoir of animal wealth and the food and cash agricultural crops. The gradual or abrupt liquidation of the public sector and state sector was a weighty component of the modern economy of the post-independence nationalist state. Influenced by globalization processes, it was unclear whether African states would resort to nationalization to complete their economic independence, or adopt measures to protect the national industry by the guidance and organization of external trade to accumulate economic surplus for development. African states might well enforce banking policies to guarantee the stability of national currency, or offer incentives to attract smuggled national capital, for example emigrant remittances, to participate in the national economy and to reinforce the basic commodities and the health and education services. "When the rich are a small minority and the poor a majority, the gap between the two would worsen off. It becomes a matter of time, which way to choose: reforms or revolutions" (Nugud, 1997; cited in Mahmoud, 2007:218).

Africa's ways to the substitutes of foreign hegemony were as difficult as the capitalist path of foreign investments was. The end of the tunnel, nevertheless, was different and was worthy of persistent determination and popular movements. The key factor was the African negotiator who contended with foreign investors and who would commit above all to the needs and aspirations of the indigenous populations - the centuries' most deprived victims of both local and foreign hegemony. The strength of African negotiators could be founded on popular support for which sake the largest margins of public freedoms and the full enjoyment of human rights would be fully guaranteed by the African state. Under this humanitarian umbrella of democratic rule, the exercise of freedom of the press and expression and the freedom of assembly and organization would 
restore the civil society status and role in the African modern societies - the trade unions and professional associations which led the successful preindependence and post-independence struggles before Africa fell to the tyrannies of authoritative rule. To strengthen democratic governance in Africa, the text and action of the African Union's Commission on Human and Peoples' Rights should be firmly reformed to meet the challenges of progression.

The effort thus far made to resolve the Darfur Crisis was seriously short of the national democratic agenda, namely the surrender of Omer Bashir and his military and political accomplices to the International Criminal Court (ICC) to account for crimes against humanity in Darfur, the return of all displaced Darfuris to their lands with full compensations to the victims of war, and the establishment of autonomous rule of the region within a unified democratic Sudan. Diplomatic moves by the post-Mandella South African government, representatives, and lawyers to release Bashir from the ICC indictment were entirely rejected by the Darfuris (Simpson \& Adam, 2014; Darfur Union in the UK, 2017) and opposition groups. The democratic agenda alone would end "the persistent violence against civilians, [the] complete disregard of basic humanitarian and human rights norms, the fact that no significant return of IDPs [Internally Displaced Persons] and refugees has taken place, the continued attacks against humanitarian workers, the precarious situation at the Chad/Sudan border, and the inability of the Sudanese parties to conclude a peace agreement” (African Union PSC, 2006).

\section{Conclusion}

Early in 1885, the Haitian thinker Joseph Anténor Fermin theorized the anthropological unity of humanity as he taught, "human species with its unique constitution and organic uniformity... based upon a single blueprint, appeared in various parts of the world, under strictly identical conditions... Whatever transformations the different groups have undergone... they all retain the primordial constitutional imprint of the species, bearing the same intellectual and moral traits inscribed in the original common human blueprint." Fermin's hypothesis "stood the test of time, unlike those proposed by the polygenists he was confronting” (Fluehr-Lobban, 2000:457).

There was much shared between Middle-East nations, especially the Gulf States, and the African peoples with respect to culture, religion, languages, marriages and alliances. A history of magnificent civilizations cemented the social and political connections and the mutual concerns for freedom, equity, justice, and economic prosperity tied up the two entities since old ages. The Prophet's Hadith, "My family is white, red, and black," spoke to the oneness of humanity in the universality of Islam which 
prescribed the rightful commercial and social contacts between individuals and groups. Watching the oppression and prejudices against the African and Asian workers, these Islamic teachings were seriously ignored. Although the Saudi, Kuwaiti, and Middle-Eastern relief efforts in Africa were commendable in contemporary times, the thorny conditions of foreign workers in the Gulf were non-compliant with international norms. The Gulf businesses failed to demonstrate clear adherence to ILO standards, according to authentic sources.

This paper emphasized the urgent need to ensure sustainable development for the African peoples in markets free of exploitation and abuses of authority. Added to the condemned killings, dehumanization of people, and destruction of heritage and property by the investing materialism, the financial management of large projects was strongly questioned without response from national governments or foreign contractors. This unlawful silence was nothing but proof of the nontransparency of the partners. The African resistance to the causes and effects of these ills never ceased to exist. Middle-Eastern governments and businesses were strongly asked, on equal terms with African leaderships and ruling elites, to cherish the significance of the indigenous transactions and cultural values. These value-orientations had been placed in the upper echelons of the Pan-African heritage, far beyond the immediate advantage of foreign debt services and trade surpluses. National rulers, foreign investors, and international agencies were called upon to incorporate the Continent's values, spirit and text, onto the political, financial, and economic actions.

The continuous perfection of facilities and free markets for foreign investments by the present-day African lawmakers entrenched the notorious policies that depleted the continent of its resources at expense of the vast majority of people. State managers and investment commissioners in Africa were equally responsible for this situation: as rulers and domineering elites they were required to service the African communities with honesty to increase social progression and economic advancement. The governments and/or businesses of the Gulf, China, Iran and Turkey went as far as assaulting the human rights of African peoples by unprecedented support to the continent's most repressive rulers. All Middle-Eastern, Chinese, and foreign investors were urgently required to avoid the past colonial and/or neo-colonial experiences that stripped the land and manpower of the Continent of Africa, seated a power-thirst middle class in authoritarian systems of rule, and impoverished the working class, farmers, and lowincome professionals with lasting poverty.

The Gulf States seemed to have developed welfare indicators towards the wellbeing of their citizens by low IMR, increased literacy, and sufficient financial support to local businesses and international enterprises. The 
relatively high transparency index of Gulf States compared to the low index of African states did not restrain the Gulf businesses and China from making multi-million deals with low transparency governments, irrespective of conditionality of public participation and auditing. The investments thus far applied were protected by all-investor sureties; even training requirements for nationals were not firmly stipulated. This state of affairs made of foreign investment a global perpetuation of both colonial and neo-colonial injustices. The needs of African peoples to access sustainable development, technological advancement, equalitarian opportunities and planned investments were forfeited for the immediate profits and advantages of global powers and ruling elites, as well as middle classes’ promised growth.

The ultimate mission of the African Union was not effectively observed to accomplish a successful path of Pan-African development and international cooperation to move the continent ahead in accordance with the principles of the African Charter, the Maputo Declaration and Arusha Accords. The African Union did not pay full recognition to the founding visions of the Pan-Africanist thinkers Du Bois, Diop, and Frantz Fanon and the gallant legacies of the liberation leaders, Nkrumah, Nasser, Sékou Touré, Nyerere, and Mandela. African civil society, human rights, and development NGOs envisioned an optimistic future of the Mother Continent. It is high time for Africa to review the existing investment laws with clear empowering of the public interest and the Charter's wisdom of shared governance. Similarly for the GCC states, "a fundamental recasting of statesociety relations and a reformulation of the pillars of ruling legitimacy" was earlier mentioned. Accordingly, foreign benefits must be adjusted to increase the local components of development, as necessary conditions of economic prosperity and political rest. Here, the message of Maputo Declaration (2003) to Africa governments and leaderships envisaged a wide range of continental and international obligations to "Take a united stance and common position in rejecting and rolling back agreements that have exacerbated poverty, underdevelopment and injustice.”

Based on the fundamental guarantees of Article 21-1 of the African Charter on Human and Peoples’ Rights, “All peoples shall freely dispose of their wealth and natural resources," our paper stressed the following detailed actions to redress the crisis of foreign investments in Africa: "Reclaim and retain policy space for the regulation and monitoring of the movements of capital investments and transnational corporations on the continent; Enhance intra-regional trade and harmonize policy frameworks in regional economic communities including establishment of mechanisms for regulation and control; Take collective action on the call for total and unconditional cancellation of African countries external debt, restitution of our stolen wealth and the "demand" for reparations;... Ensure participation of civil 
society to the specialized technical commissions of the African Union; Halt and reverse water privatization, biopiracy planting of GMO and life patents through national laws, collective positions and strategies at the WTO, IMF and World Bank, implementing their commitments to multilateral and regional environmental agreements, ensuring corporate accountability; Support agricultural marketing, extension services, credit and research with a gender perspective to enhance food security; Release all imprisoned African journalists and repeal all anti-free expression legislation in Africa” (Maputo Declaration, 2003).

\section{References:}

1. African Commission on Human and Peoples' Rights (ACHPR) (2017). African [Banjul] Charter on Human and Peoples Rights adopted June 27, 1981. OAU Doc. CAB/LEG/67/3 rev. 5, 21 I.L.M. 58 (1982), entered into force Oct. 21, 1986. http://www.achpr.org/files/instruments/achpr/banjul_charter.pdf (1981).

2. African Union (2006). Report of the Chairperson of the Commission pursuant to Paragraph 5 of the PSC Communique PSC/PR/Comm (XLV) of 12 January 2006 on the situation in Darfur (Peace and Security Council 46 ${ }^{\text {th }}$ Meeting 10 March 2006 Addis Ababa) http://www.peaceau.org/uploads/pscreporteng-46th.pdf

3. Agricultural Engineers' Group (2009). "Why rejecting the Gazira privatization?” SHRO-Cairo: The Sudanese Human Rights Quarterly. Issue 29, Year 15 ${ }^{\text {th }}$, May 2009, pp. 9-14.

4. Alarabiya (2016). الخارجية المصرية ترد علي دفاع مجلس التعاون الخليجي عن قطر https://arabic.cnn.com/middleeast/2016/12/16/egypt-gcc-qatar.

5. AlJazira (2016). حقوق العمال وو اجباتهم:Workers’ rights and obligations]. http://www.aljazeera.net/programs/religionandlife/2006/7/3.

6. Baali, Fuad (1988). Society, state, and urbanism: Ibn Khaldun's sociological thought. Albany: State University of New York.

7. Bandow, Doug (2017). President Elect Trump: End U.S. support for Saudi Arabia's barbaric war in Yemen. The Huffington Post: http:/www.huffingtonpost.com/doug-bandow/president-elect-trumpend_b_12911720.html.

8. Benjamin Augé (2016). "Diplomatic Relations between Qatar and Sub-Saharan Africa An Evolving Affair”, Notes de l'Ifri, August 2016.

9. BlackPast (2007). Frederick Douglass (1857), "If There Is No Struggle, There Is No Progress.” http://www.blackpast.org/1857frederick-douglass-if-there-no-struggle-there-no-progress. 
10. Bosshard, Peter (2000). New Chinese Dam Project to Fuel Ethnic Conflict in Sudan. The World Post. http://www.huffingtonpost.com/peter-bosshard/new-chinese-damproject-t_b_811384.html.

11. Bukuku, Enos \& Mahmoud, Mahgoub (1989). "Social Aspects of African Development.” In: African Development Prospects - A Policy Modeling Approach, edited by Dominick Salvatore (UN publication). New York: Taylor \& Francis.

12. Crystal, Jill (1990). Oil and politics in the Gulf Rulers and Merchants in Kuwait and Qatar. Cambridge: Cambridge University Press.

13. Dabanga (2015). Saudi Arabia to finance Sudanese agriculture, dams projects. https://www.dabangasudan.org/en/all-news/article/saudiarabia-to-finance-sudanese-agriculture-dams-projects (November 4, 2015).

14. Dahlan, Ahmed Hassan (1990). Politics, Administration and Development in Saudi Arabia, Brentwood: Amana Corporation.

15. Darfur Union in the United Kingdom (2017). نداء-هام-من-محكمة_الجنايات [Important ICC call: Darfur investigation team searches for persons to inform about certain places in West Darfur]: https://darfurunionuk.wordpress.com/2017/03/23/

16. Diop, Cheikh Anta (1963). The Cultural Unity of Black Africa. London: Karnak House.

17. Diop, Cheikh Anta (1956). Cultural Contributions \& Perspectives for Africa; Towards the African Renaissance Essays in Culture \& Development by C. A. Diop. London: Karnak House (1996).

18. Doherty, Regan (2012). Qatar's SWF to spend \$30bn in 2012. Reuters (Doha23 April 2012). Retrieved, http://www.mineweb.com/mineweb/content/en/mineweb-miningfinance-investment-old?oid=149943\&sn=Detail\&pid=102055.

19. Du Bois, W.E.B. (1935). W.E.B. Du Bois. Black Reconstruction in America. New York: Russell \& Russell, 1935, 1962. Retrieved in: http://www.webdubois.org/wdb-BlackReconst.html.

20. Economic Commission for Africa (2009). African Governance Report II 2009, UNECA. New York: Oxford University Press: http://www.uneca.org/sites/default/files/PublicationFiles/agr2english_0.pdf

21. Fluehr-Lobban, Carolyn (2000). Anténor Firmin, American Anthropologist, Vol. 102, No. 3, Sep 2000.

22. Freer, Courtney (2016). The Changing Islamist Landscape of the Gulf Arab States. The Arab Gulf States Institute in Washington, Issue paper No. 9 November 21, 2016:http://www.agsiw.org/wpcontent/uploads/2016/11/Freer_ONLINE-1.pdf 
23. Gebre-Mariam, Tsige; Kedir Tahir and Solomon Gebre-Amanuel (2016). "Bringing Industrial and Health Policies Closer: Reviving Pharmaceutical Production in Ethiopia” in: Maureen Mackintosh et al (2016). Making Medicines in Africa: the Political Economy of Industrializing for Local Health. England: Palgrave Macmillan. http://apps.who.int/medicinedocs/documents/s22195en/s22195en.pdf.

24. Gengler, Justin, Mark Tessler, Darwish Al-Emadi and Abdoulaye Diop (2011). "Civil society and democratization in the Arab Gulf." Foreign Policy: http://foreignpolicy.com/2011/07/25/civil-societyand-democratization-in-the-arab-gulf (July 25, 2011).

25. Gresh, Alain (2016). A Turbulent Time in Saudi-Egyptian Relations. ORIENT XXI: http://orientxxi.info/magazine/a-turbulent-time-insaudi-egyptian-relations, 1627 (12/14/2016).

26. Gulf News (2016). Qatar is supporting civil society groups: minister. http:/www.gulf-times.com/story/489516/Qatar-is-supporting-civilsociety-groups-minister (April 21, 2016).

27. Hafez, Mohammed M. (2003). Why Muslims Rebel - Repression and Resistance in the Islamic World. Boulder: Lynne Rienner Publishers.

28. Halliday, Fred (2003). Islam and the Myth of Confrontation Religion and Politics in The Middle East. London: I. B. Tauris.

29. Hawamir alBorasa Alsaudiya (2016). قرارات وتوصيات مجلس الشورى [Comments on decisions and recommendations of the Shura Council on military retirement] http://www.hawamer.com/vb/showthread.php?t=708728.

30. Hughes, A. I. (1969). East Africa, Kenya, Tanzania, Uganda. Baltimore: Penguin Books (revised).

31. Human Rights Watch (2014). Gulf Countries: Increase Migrant Worker Protection. New York: https://www.hrw.org/news/2014/11/23/ Gulf, Asian Labor Ministers at 3rd Abu Dhabi Dialogue, Nov 23, 2014.

32. Ibn Khaldun, 'Abd al-Rahman (1997). Muqadimat ibn Khaldun. Beirut: Dar al-Fikr al-'Arabi.

33. Ibrahim, Saad Eddin (1996). Egypt, Islam, and Democracy. Cairo: American U. Press.

34. International Campaign to Defend the Gazira and Manaqil (2006). in: al-Siddiq AbuAsharah Mashru al-Gazira wa Jarimat Qanun Sanat Philadelphia: Muassasat al-Iqtisadi al-Sudani (Beirut, 2011).

35. International Rivers (2010). Kajbar Dam, Sudan. Retrieved from: https://www.internationalrivers.org/campaigns/kajbar.

36. Iran News Update (2014). Iran has a significant role in Sudan's arms industry. Irannewsupdate.com/news/terrorism/1151 (13 May 2014). 
37. Karenga, Maulana (1993). Introduction to Black Studies. Los Angeles: University of Sankore Press.

38. el-Kikhia, Mansour (1997). Libya's Qaddafi. Gainesville, Fla: University Press of Florida.

39. Lapidus, Ira M (2002). A History of Islamic Societies. New York: Cambridge University Press.

40. Los Angeles Times (2017). Saudi land purchases in California and Arizona fuel debate over water rights. (25 May 2017). www.latimes.com/business/la-fi-saudi-arabia-alfalfa-20160329story.html.

41. MacDermot, Niall (1989). "The Role of Non-Governmental Organizations in the Promotion of Human Rights. " ICJ, The role of non-governmental organizations in the promotion and protection of human rights, Amsterdam: Stichting NJCM-Boeke- rij (November 22nd 1989).

42. Macro History and World Time (2007). Muslim Conquests in Egypt and Iran. Retrieved from: http://www.fsmitha.com/h3/islam08b.htm (2007-2015 by Frank E. Smitha).

43. Mahmoud, Mahgoub (2007). Linkages among African and AfricanAmerican Thinkers: The Emergence of a Trans-geographical Intellectual Community. Lewiston: Edwin Mellen Press.

44. Mahmoud, Mahgoub E. (2005). Human Rights in Africa. Lewiston: Edwin Mellen Press.

45. Malawi Today (2012). Malawi debt hits 54 percent of GDP. Retrieved from: http:/www.malawitoday.com/news/127345malawi-debt-hits-54-percent-gdp (22).

46. Mazrui, Alamin and Willy Mutunga (2003). Ali Mazrui on the Cult of African Leaderships. Governance and Leadership: Debating the African Condition Mazrui and His Critics. Volume II: Trenton, NJ: Africa World Press, Inc.

47. Mijares, Isabel Del Toro (2017). The Forgotten War: The Conflict in Yemen and the Crisis of Global Leadership, The Politic. http://thepolitic.org/the-forgotten-war-the-conflict-in-yemen-and-thecrisis-of-global-leadership/(March 23, 2017).

48. Mirna Seliman (2013). Wealthy Gulf Arab investors warm to Africa. Reuters: http://www.reuters.com/article/2 (January 2, 2013).

49. Mutua, Mkau (2000). The African Human Rights System A Critical Evaluation. hdr.undp.org/sites/default/files/mutua.pdf.

50. Nugud, Mohamed Ibrahim (1997). "Renewing a Socialist Democratic Party in Sudan.” Cited in: Mahmoud, Mahgoub E. (2007), Linkages among African and African-American Thinkers op. cit. 
51. Orient Net (2016). لماذا أوقفت السعودية إمداد البترول لمصر ]Why the Saudi suspended oil from Egypt] http://orientnews.net/ar/news_show/124864/ (10.10.2018).

52. Ottaway, Marina (1998). Africa's New Leaders - Democracy or State Reconstruction. Washington, D.C.: Brookings Institution Press.

53. Oxford Business Group (2013). Saudi Arabia: overseas investments to boost food security. http://www.oxfordbusinessgroup.com/economic_updates/saudiarabia (9 May 2013).

54. Ponzanesi, Sandra and Gianmaria Colpani (2016), Postcolonial Transitions in Europe. Contexts, Practices and Politics. London, Rowman and Littlefield.

55. Reem Abbas (2013), Sudan Nile Dam Threatens Nubian villages. Almonitor, monitor.com/pulse/originals/2013/05/sudan-kajbar-dam-

http://www.alnubians.html.

56. Rejwan, Nissim (1998). Arabs Face the Modern World. Gainesville, FL: University Press of Florida.

57. RT (2016). Qatar and Saudi Criticisms of Egypt's Vote for the Russian Proposal on Syria in the Security Council: https://arabic.rt.com/news/844415 (9-10-2016).

58. Sciolino, Elaine (1991). The Outlaw State - Saddam Hussein's Quest for Power and the Gulf Crisis, New York: John Wiley \& Sons, Inc.

59. SHRO Taayush Association (2009). "Who enjoyed the State's "religious economy." The Sudanese Human Rights Quarterly. Issue 29 , Year $15^{\text {th }}$, May 2009, pp. 15-21.

60. Shura Council (2016). Shura in the Kingdom of Saudi Arabia: A Historical Background. https://www.shura.gov.sa/wps/wcm/connect/ShuraEn/internet/Histori cal+BG/

61. Simpson, Matthew T. and Ahmed H. Adam (2014). Don't Decriminalize War. Shrocairo_updated.org. (February 17, 2014).

62. Soyinka, Woll (1975). Death and the King's Horseman A Play. London: Norton \& Company (2002).

63. The Guardian (2014). Sudan's anti-dam movement fights the flooding of Nubian culture. https://www.theguardian.com/world/2014/dec/12/sudans-anti-dammovement-fights-the-flooding-of-n ubian.

64. TheNewArab (2016). 2016 a bleak year for journalists in the Gulf: https://www.alaraby.co.uk/english/indepth/2016/12/31/2016-a-bleakyear-for-journalists-in-the-gulf. 
65. Tibandebage, Paula; Samuel Wangwe; Maureen Mackintosh; and Phares Mujinja (2016). "Pharmaceutical manufacturing Turnaround in Tanzania: How possible is a Turnaround to Growth,” in: Maureen Mackintosh et al (2016). Making Medicines in Africa: the Political Economy of Industrializing for Local Health. Op. cit.

66. Transparency International (2012). International transparency corruption index. Retrieved from: http://www.transparency.org/cpi2012/results.

67. Veto (2017). أدلة تكثف نواطؤ أمين التعاون الخليجي ضد مصر/25idence on GCC collaboration against Egypt] http://www.vetogate.com/2503387 - posted 16 December 2016 (updated 15 April 2017).

68. Udogu, E. Ike (2016). Leadership and the Problem of Electoral Democracy in Africa. Case Studies and Theoretical Solutions. London: Cambridge Scholars Publishing.

69. Ulrichsen, Kristian Coates (2015). Insecure Gulf the end of certainty and the transition to the post-oil era. New York: Oxford University Press.

70. UNCTAD (2013). World Investment Report 2013, Global value chains: Investment and Trade for Development. New York: http://unctad.org/en/PublicationsLibrary/wir2013_en.pdf.

71. UN Watch (2016). US, EU Must End "Deafening Silence" on Abusers' Election to UNHCR: https://www.unwatch.org/145632/(Geneva: October 27, 2016).

72. U.S. Department of State (2016). Country Reports on Human Rights Practices for 2016: United Arab Emirates. https://www.state.gov/j/drl/rls/hrrpt/2005/61701.htm.

73. U.S. Department of State (2016). Qatar 2016 Human Rights Report Executive Report Summary. https://www.state.gov/documents/organization/265728.pdf.

74. U.S. Department of State (2016). Saudi Arabia 2015 Human Rights Report Executive Report Summary. https://www.state.gov/documents/organization/253157.pdf.

75. Weissbrodt, David and Anti-Slavery International (2002). Abolishing Slavery and its Contemporary Forms. New York: OHCHR http://www.ohchr.org/Documents/Publications/slaveryen.pdf.

76. Willis, Michael (1996). The Islamist Challenge in Algeria - A Political History. NY: NYUP.

77. Wiseman, John A. (1998): “The Gambia from Coup to Elections," in: Journal of Democracy, Volume 9, Number 2, pp. 64-75, April 1998, Washington, DC: Ned, John Hopkins University Press.

78. World Bank (2012). http//: data.worldbank.org. World Bank. 
79. World Post (2017). Top 10 Worst Countries for Workers’ Rights: The No Ranking Country Should Want. http://www.huffingtonpost.com/sharan-burrow/top-ten-worst-countriesf_b_7553364.html 